\title{
Biological Responses of the Rat to Polychlorinated Biphenyls ${ }^{1}$
}

\author{
J. V. Bruckner, K. L. Khanna AND H. H. Cornish \\ Department of Environmental and Industrial Health, School of Public Health, \\ University of Michigan, Ann Arbor, Michigan 48104
}

Received May 3, 1972

\begin{abstract}
Biological Responses of the Rat to Polychlorinated Biphenyls. BRUCKNER, J. V., Khanna, K. L. and Cornish, H. H. (1973). Toxicol. Appl. Pharmacol. 24, 434-448. A commercial polychlorinated biphenyl mixture (PCBs), Aroclor 1242, was administered to rats po by intubation in order to determine toxic manifestations of acute and subacute ingestion. In addition, the effect of PCBs on hepatic microsomal enzyme systems in rats was evaluated. The oral, 14-day LD50 was determined to be approximately $4.25 \mathrm{~g} / \mathrm{kg}$. Major toxic signs observed upon administration of high doses of PCBs included diarrhea, chromodacryorrhea, loss of body weight, unusual stance and gait, lack of response to pain stimuli, and terminal ataxia. Progressive dehydration and CNS depression appeared to be contributing factors in each fatality. Histopathologic alterations were evident only in the liver and kidneys, manifest as foci of sudanophilic vacuolation. Rats maintained on an oral dosage regimen of $100 \mathrm{mg} / \mathrm{kg}$ every other day for 3 weeks exhibited similar histopathologic changes, but no overt signs of toxicity. Serum GOT activities were elevated over controls in both the acute and subacute groups. A single ip injection $(100 \mathrm{mg} / \mathrm{kg})$ increased liver weight, total hepatic microsomal enzyme activity (measured as hydroxylation of acetanilide and $\mathrm{N}$-demethylation of aminopyrine), and hepatic cytochrome $\mathrm{P}_{450}$ and $b_{5}$ levels. Hepatic microsomal enzyme activity remained elevated 10 days after a single dose of PCBs, suggesting that PCBs may play an important role in altering biologic responses of mammals subjected to environmental chemical stress.
\end{abstract}

Polychlorinated biphenyls (PCBs) have experienced widespread industrial usage and are now widely distributed throughout the environment (Gustafson, 1970; Peakall and Lincer, 1970). These compounds have been found in the livers of dying pelagic birds (Bourne and Mead, 1969), in fish, mussels, and birds (Koeman et al., 1969), and even in human adipose tissues (Biros et al., 1970). Humans have been inadvertently exposed to PCBs in several instances, including ingestion of PCB-contaminated rice oil in Japan (Kuratsune, 1969), and poultry products in the United States (Pichirallo, 1971).

Data on the precise chemical composition and the toxicity of PCBs is at present incomplete. Commercial PCB products are known to consist of mixtures of isomers, differing from one another in the degree of chlorination. Vos and co-workers (1970) reported 2 such products, Clophen and Phenoclor, to be contaminated by trace amounts of chlorinated naphthalenes and highly poisonous chlorinated dibenzofurans. Chlorinated dibenzofurans have been implicated in the toxic action of Clophen and Phenoclor,

${ }^{1}$ This investigation was supported in part by U.S. Public Health Service Grant GM 15269.

Copyright (C) 1973 by Academic Press, Inc. All rights of reproduction in any form reserved. 
both of which were found to be more toxic than equivalent levels of an analogous Aroclor preparation (Vos and Koeman, 1970; Vos and Beems, 1971).

Little basis exists for assessing the injury potential posed by PCBs to humans and other mammals on acute or prolonged exposures. Manifestations of hepatic and renal toxicity on prolonged administration of PCBs have been reported in chickens (Vos and Koeman, 1970), in quail (Vos et al., 1971) and in rabbits (Vos and Beems, 1971). PCBs have been shown to induce liver microsomal enzyme activity (Fujita et al., 1971). This action of PCBs on the microsomal enzyme system may exert a significant effect on the metabolism of not only certain endogenous substances, but also exogenous compounds including halogenated hydrocarbon pesticides and drugs. The present investigation was undertaken to determine toxic manifestations of acute exposure to high levels of a typical PCB preparation, Aroclor 1242. In addition, the effect of single and repeated doses of Aroclor 1242 on hepatic microsomal enzyme systems was evaluated.

\section{METHODS}

Male, Sprague-Dawley rats, ${ }^{2} 200-300 \mathrm{~g}$ body weight, were utilized in the present study. All animals were maintained at room temperature, with Rockland rat and mouse chow and tap water available ad libitum except as indicated. The rats were housed in stainless steel cages in groups of 2 or 3 animals per cage. Only during collection of urine specimens were animals confined individually in metabolism cages.

Aroclor $1242^{3}$ was administered undiluted in each instance in which the dose was $\geqslant 500 \mathrm{mg} / \mathrm{kg}$. A $1: 10$ dilution of Aroclor 1242 in peanut oil was utilized for dosing at the $100 \mathrm{mg} / \mathrm{kg}$ dosage level. Control animals received a comparable volume of peanut oil. Oral doses were administered with a blunt-tip, metal intubation needle. Intraperitoneal injections were given with a standard 22 gauge needle to facilitate flow of the rather viscous test solution.

An oral LD50 value was calculated according to the method outlined by Litchfield and Wilcoxon (1949). All deaths occurring within 14 days of dosing were included.

Hematology. Blood samples were taken from tail veins for blood smears and packed cell volumes. Each packed cell volume reported represents an average of two determinations per rat. Blood smears were stained with Wright's stain, then examined microscopically for erythrocyte morphology and differential leukocyte counts. Serum sodium and potassium concentrations were measured utilizing a Perkin Elmer 403 atomic absorption spectrophotometer. Final values were calculated in terms of $\mathrm{mEq}\left(\mathrm{Na}^{+}\right.$or $\left.\mathrm{K}^{+}\right)$/liter.

Histopathology. Tissue samples were rapidly excised after sacrifice and placed into $10 \%$ formalin overnight for fixation. The tissues were then embedded in paraffin, sectioned, and stained with hematoxylin and eosin for light microscopic examination. Kidney and liver specimens were also processed and stained for lipid with Sudan IV. Light micrographs were taken with a Zeiss photomicroscope. Fresh tissues were observed under UV light for evidence of fluorescence.

Enzyme assays. After anesthetization with ether, as much blood as possible was

${ }^{2}$ Spartan Research Farm, Lansing, Michigan.

${ }^{3}$ Lot No. KA419. Kindly supplied by Monsanto Chemical Company, St. Louis, Missouri. 
withdrawn by open-chest cardiac puncture. Five-gram liver samples were removed and individually homogenized in $10 \mathrm{ml}$ of cold $1.15 \% \mathrm{KCl}$ in $0.05 \mathrm{M}$ Tris buffer (pH 7.4). Tissues were homogenized in glass homogenizers by making three 10 -sec passes with a Teflon pestle fitted to a standard drill press. Each sample was then centrifuged in the cold at 13,000 $\mathrm{g}$ for $20 \mathrm{~min}$. Portions, $1 \mathrm{ml}$, of the resultant supernatant were then combined with $2 \mathrm{ml}$ of phosphate buffer $\mathrm{pH} 7.4$ and $2 \mathrm{ml}$ of a cofactor solution containing the following: $25 \mu \mathrm{M}$ glucose 6-phosphate, $2.25 \mu \mathrm{M} \mathrm{NAD}, 20 \mu \mathrm{M}$ nicotinamide, $2.25 \mu \mathrm{M}$ NADP, $12 \mu \mathrm{M} \mathrm{MgSO}_{4}$, and substrate (3.5 $\mu \mathrm{M}$ aminopyrine for $\mathrm{N}$-demethylation determination, $17.8 \mu \mathrm{M}$ acetanilide for hydroxylation determination). Each 5-ml sample was then incubated for $20 \mathrm{~min}$ at $37^{\circ} \mathrm{C}$ in a Dubnoff shaker under an atmosphere of oxygen.

Microsomal hydroxylation activity was evaluated by determination of $N$-acetyl- $p$ aminophenol formation from acetanilide incubation samples. The procedure of Brodie and Axelrod (1948) for determination of total conjugated $p$-aminophenol was followed, with the following minor modifications. Each $5-\mathrm{ml}$ incubation sample was combined with $1 \mathrm{ml}$ of $6 \mathrm{~N} \mathrm{HCl}$, transferred to a test tube topped with a glass marble to retard evaporation, and placed into a boiling water bath for $30 \mathrm{~min}$. The content of each tube was then cooled, combined with $5.24 \mathrm{~g} \mathrm{~K}_{2} \mathrm{HPO}_{4} \cdot 3 \mathrm{H}_{2} \mathrm{O}$ and shaken with $20 \mathrm{ml}$ of anhydrous ether. Fifteen-milliliter aliquots of the ether fraction were then assayed for $p$ aminophenol content according to the aforementioned procedure.

Microsomal N-demethylation activity was evaluated by determination of 4-aminoantipyrine formation from aminopyrine. At the end of the 20 -min incubation period, the reaction occurring in each flask was stopped by addition of $15 \mathrm{ml}$ of $6.7 \%$ trichloroacetic acid, and the precipitated protein was removed by filtration. A 5-ml portion of each filtrate was then assayed for 4-aminoantipyrine by the method of Brodie and Axelrod (1950). The 5-ml filtrate aliquots utilized in the present study correspond to the $5 \mathrm{ml}$ of supernatant aqueous phase referred to by Brodie and Axelrod. Transmittance readings for both the hydroxylation and $\mathrm{N}$-demethylation determinations were determined with a Bausch and Lomb Spectronic 20 spectrophotometer.

Serum glutamic oxaloacetic transaminase (SGOT) activity was determined in serum samples by a standard procedure (Sigma, 1963). Serum was prepared from the blood spccimens obtained by open-chest, cardiac puncture.

All protein concentrations were determined by the biuret method (Robinson and Hogden, 1940).

Cytochrome $P_{450}$ and cytochrome $b_{5}$ determinations. The method outlined by Omura and Sato (1964), with the following minor alterations, was utilized in the determination of the hepatic microsomal cytochromes $P_{450}$ and $b_{5}$. The animals werc ancsthetized with ether and their livers were perfused in situ. Two, rather than 4 , volumes of $1.15 \% \mathrm{KCl}$ were used for homogenization of liver samples. Phosphate buffer, $\mathrm{pH} 7.4,10 \mathrm{ml}$ per sample, was used to resuspend the microsomal pellets. Cytochrome determinations were performed the same day. Phosphate buffer $(\mathrm{pH} 7.4)$ was again used to dilute the microsomal fraction to an approximate protein concentration of $2 \mathrm{mg} / \mathrm{ml}$. Approximately $1 \mathrm{mg}$ of sodium dithionite was used to reduce the cytochrome $\mathrm{P}_{450}$ in each sample. A Beckman DK-2A spectrophotometer was utilized in absorbancy measurements.

All results were analyzed statistically by Student's $t$ test. 


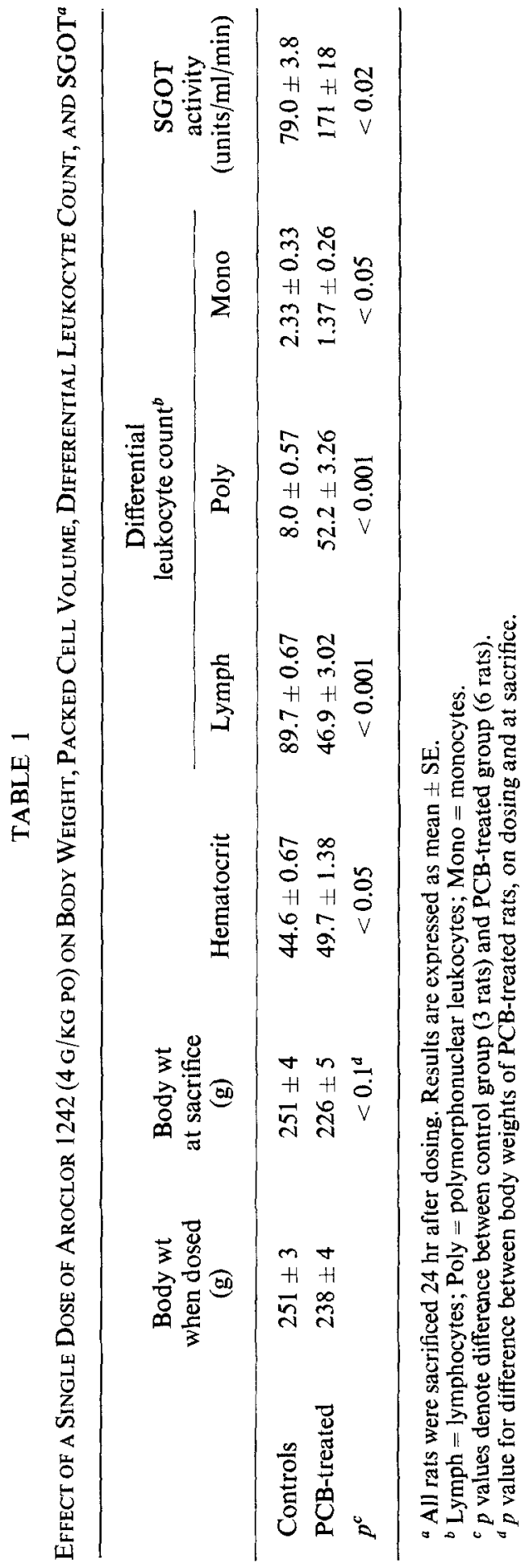




\section{Preliminary Studies}

\section{RESULTS}

Since limited acute toxicity data are available on oral administration of PCBs to mammals, a preliminary investigation was carried out with Aroclor 1242 in rats. The minimum, lethal oral dose of Aroclor 1242 was $2.5 \mathrm{~g} / \mathrm{kg}$, at which dose a single fatality occurred in a group of 6 rats observed for $72 \mathrm{hr}$. The 14-day oral LD50 for rats was found to be approximately $4.25 \mathrm{~g} / \mathrm{kg}$, with a $95 \%$ confidence interval of $2.80-6.38 \mathrm{~g} / \mathrm{kg}$.

Initial signs were remarkably similar in animals receiving Aroclor 1242 at dose levels of 2.5 and $6 \mathrm{~g} / \mathrm{kg}$. At $4 \mathrm{hr}$ after dosing, loose stools, diminished exploratory behavior, decreased response to pain stimuli, and mild chromodacryorrhea were observed in rats in each group. An unusual stance and gait were also manifest, characterized by a moderate arching of the back and elevation of the posterior portion of the trunk.

The condition of each animal at the higher dosage level progressively worsened during the next $24 \mathrm{hr}$. Profuse diarrhea and chromodacryorrhea, adipsia, oliguria, anorexia, erythema of limbs, lack of response to moderate pain stimuli, and weakness were prominent. Eventual ataxia, coma, and death followed. With the exception of a single fatality, the condition of each animal at the lower dosage level gradually improved after the initial $24 \mathrm{hr}$. Only a slight degree of oliguria and anorexia was discernible $72 \mathrm{hr}$ after dosing.

Manifestations of toxicity were not apparent in any subject receiving either 100 or $1000 \mathrm{mg} / \mathrm{kg}$ po. Control animals administered $2 \mathrm{ml}$ of peanut oil exhibited no diarrhea or any other ill effect.

An additional group of 6 rats received $6 \mathrm{~g} / \mathrm{kg}$ po of Aroclor 1242. The body weight and packed cell volume of each animal was measured at 6 -hr intervals for a period of $30 \mathrm{hr}$ after dosing, in order to monitor the dehydrating effect of the toxicant. Progressive dehydration was observed in each animal, as evidenced by steadily decreasing body weight and increasing packed cell volume. Mean values \pm SE for packed cell volume (\%) and body weight $(\mathrm{g})$ were measured at the designated times following dosing: $0 \mathrm{hr}-$ $43 \% \pm 0.4 \%, 247 \mathrm{~g} \pm 2.6 \mathrm{~g} ; 6 \mathrm{hr}-52 \% \pm 0.6 \%, 231 \mathrm{~g} \pm 2.4 \mathrm{~g} ; 12 \mathrm{hr}-56 \% \pm 0.7 \%$, $222 \mathrm{~g} \pm 2.9 \mathrm{~g} ; 24 \mathrm{hr}-64 \% \pm 1.2 \%, 213 \mathrm{~g} \pm 3.3 \mathrm{~g} ; 30 \mathrm{hr}-69 \% \pm 0.8 \%, 209 \mathrm{~g} \pm 3.6 \mathrm{~g}$. Adipsia and oliguria were exhibited by all animals.

On the basis of preliminary findings, an oral dosc of Aroclor 1242 of $4 \mathrm{~g} / \mathrm{kg}$ was selected for more inclusive studies. Control rats received an equivalent amount of peanut oil. Animals were sacrificed for acute studies $24 \mathrm{hr}$ after dosing (Table 1). PCB-treated animals exhibited a reduction in body weight, accompanied by an elevation in packed cell volume over control values. All PCB-treated subjects consumed little water or food, and subsequently developed oliguria. Differential leukocytc counts revealed that PCB-treated rats possessed a greater proportion of polymorphonuclear leukocytes than did control rats. Many erythrocytes in smears prepared from blood of PCB-dosed animals were crenated. SGOT activity was elevated in relation to control values. Neither serum $\mathrm{Na}^{+}$and $\mathrm{K}^{+}$concentrations nor blood $\mathrm{pH}$ values were altered significantly by the treatment with Aroclor 1242.

No gross pathologic alterations were evident other than minute, pale foci in livers of the rats dosed with Aroclor 1242. Tissues taken for histopathologic examination included sections of pancreas, adrenals, spleen, liver, kidneys, stomach, intestine, heart, lung, brain, and skin. All organs appeared normal except the liver and kidneys. 
The livers of both PCB-treated and control subjects were diffusely infiltrated by sudanophilic material, although the finding was more prominent in the former group. Hepatocytes in the PCB-treated group showed more extensive involvement, with large cytoplasmic vacuoles and a marked increase in cytoplasmic volume (Fig. 1). The fatty deposits appeared initially in regions encompassing the central veins. The areas of such involvement increased with time of PCB exposure, involving entire lobules within $72 \mathrm{hr}$. Necrotic foci, exhibiting karyolytic and karyorrhexic nuclei in more severely vacuolated hepatocytes, were distributed throughout these livers (Fig. 2).

The kidneys of the PCB-dosed rats contained widely scattered foci of vacuolated

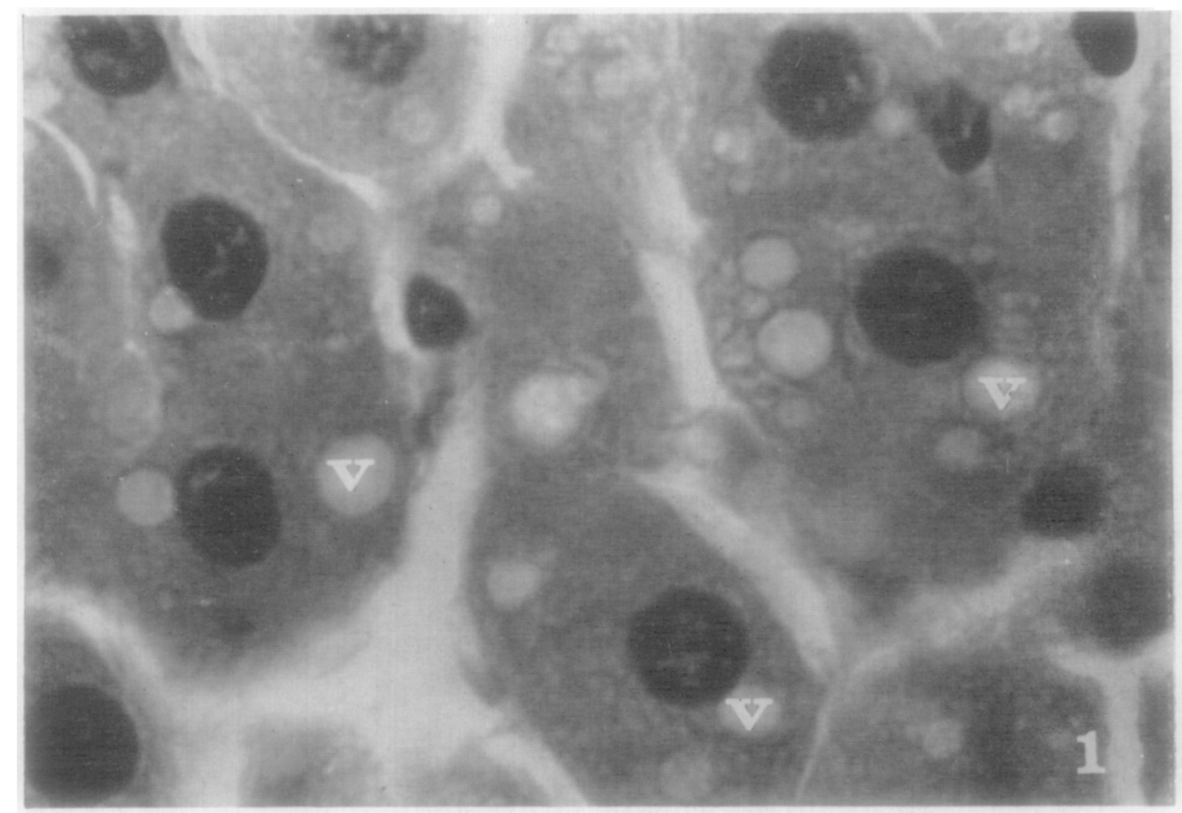

FIG. 1. Hepatic cells, of a rat dosed orally with $4 \mathrm{~g} / \mathrm{kg}$ of Aroclor 1242, showing discrete cytoplasmic vacuoles (v). Compare with homogeneous distribution of small vacuoles in Fig. 4. Hematoxylin and eosin. $\times 1200$.

tubular epithelial cells. These vacuoles proved to be sudanophilic, like those in hepatocytes. Epithelial cells were observed in tubular lumens throughout the kidney, frequently accompanied by proteinaceous casts (Fig. 3). Kidneys of control animals, however, showed no significant morphologic abnormalities. An increase in epithelial cells and in leukocytes was noted in the urine of the PCB-treated animals.

\section{Subacute Studies}

Six rats were dosed po every other day with $100 \mathrm{mg} / \mathrm{kg}$ of Aroclor 1242 for a period of 3 weeks. Similarly, 3 control rats received $100 \mathrm{mg} / \mathrm{kg}$ of peanut oil (Table 2). No signs of toxicity were manifest in any animal. Body weights of control and test animals were not significantly different at the end of the 3-week period. The liver, kidneys, heart, spleen, and adrenals of all rats were weighed and expressed in gram of organ weight/per $100 \mathrm{~g}$ of body weight. Only livers of PCB-treated subjects showed a significant weight alteration from controls (Table 2). Packed cell volumes were lower in the treated rats than in controls. 


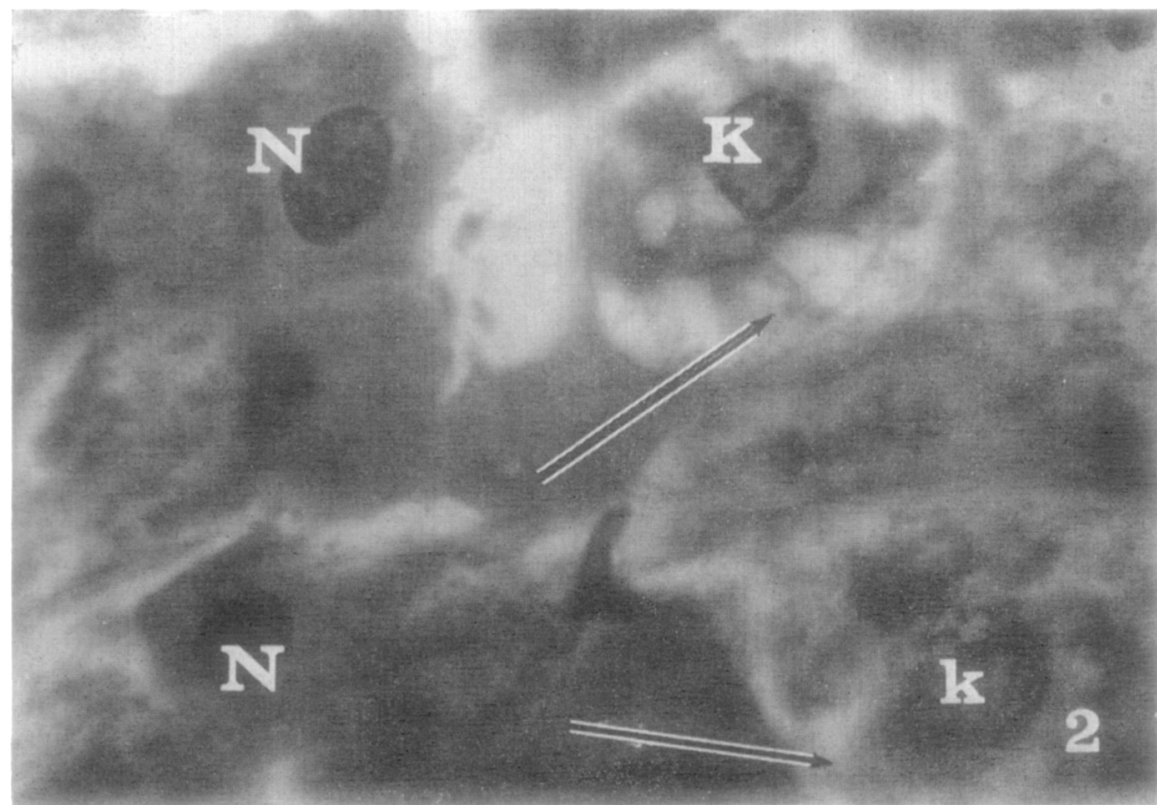

Fig. 2. Hepatocytes from an animal treated as in Fig. 1. Contrast the appearance of the more normal cells $(N)$, with the severely vacuolated cells (arrows) exhibiting karyolytic $(\mathrm{K})$ and karyorrhexic $(\mathrm{k})$ nuclei. Hematoxylin and eosin. $\times 1200$.

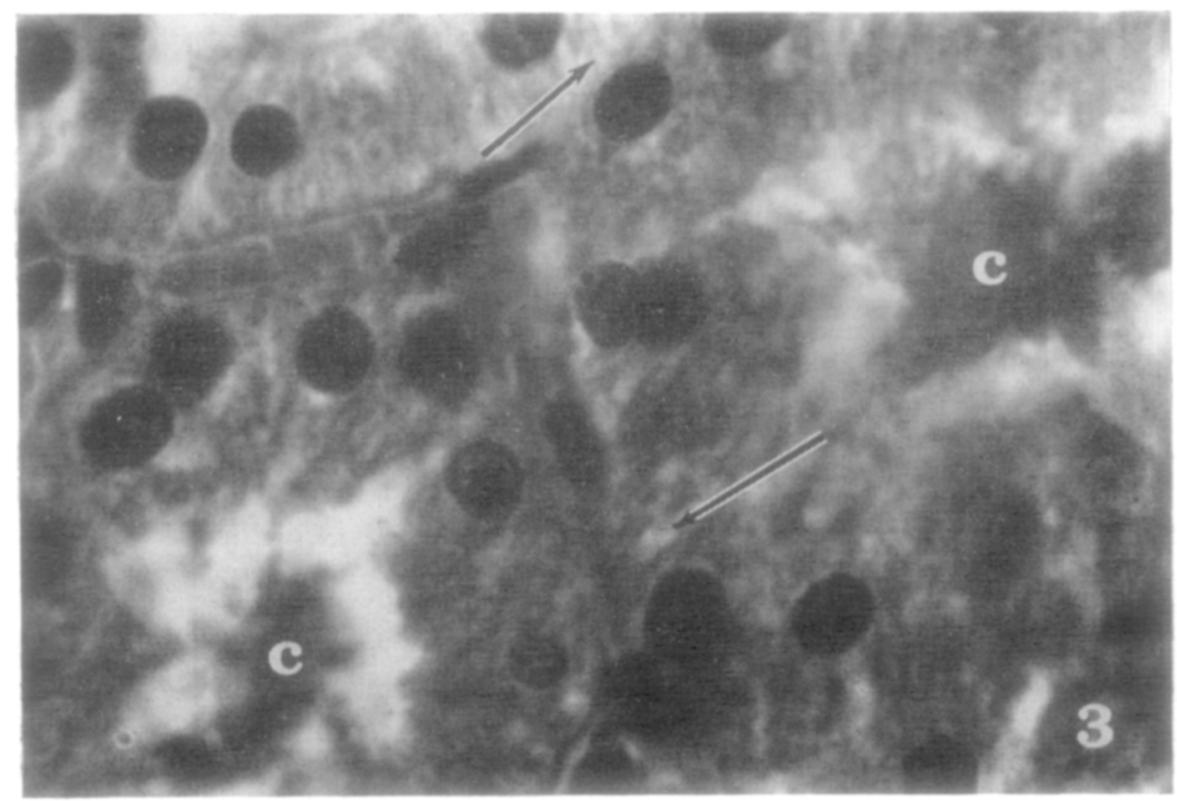

Fig. 3. Renal convoluted tubules of a rat dosed orally with $4 \mathrm{~g} / \mathrm{kg}$ of Aroclor 1242. Note the lack of cytoplasmic homogeneity (arrows) and the prominent proteinaceous casts (c). Hematoxylin and eosin. $\times 1200$. 


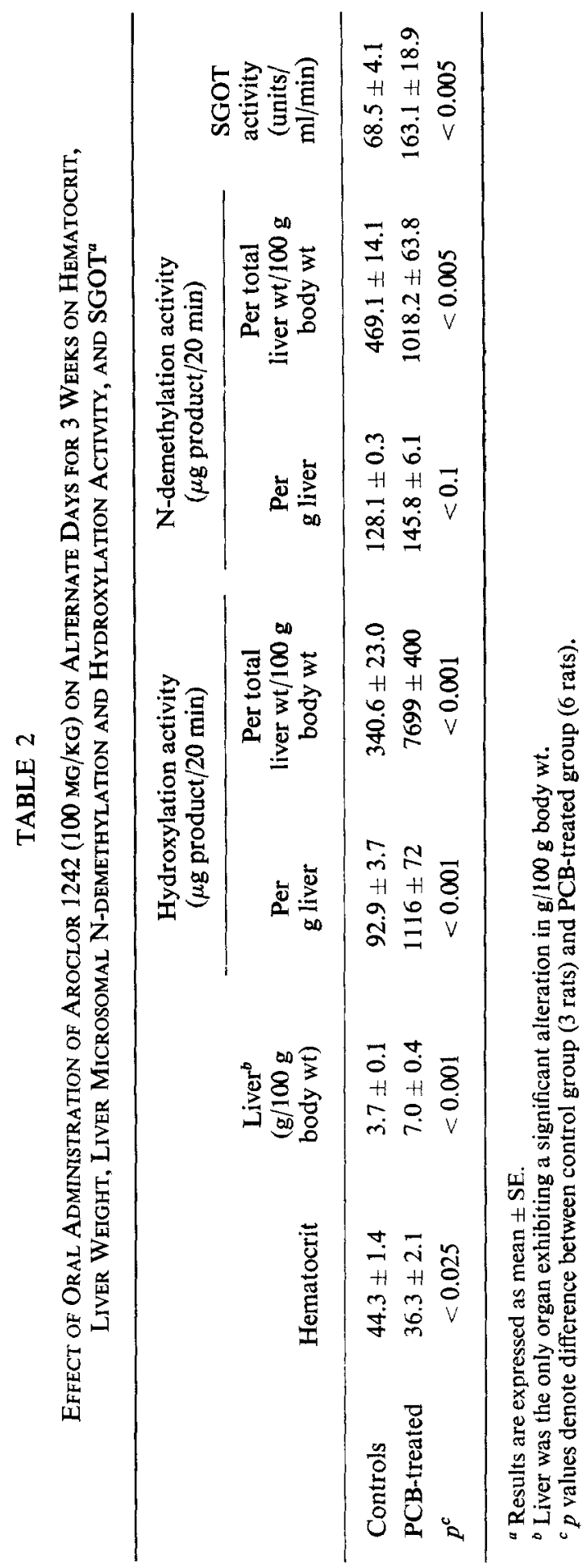


Histopathologic findings were quite similar to those previously ascribed to the single dose of $4 \mathrm{~g} / \mathrm{kg}$ of Aroclor 1242. Specimens from each animal of brain, lung, heart, liver, kidney, spleen, adrenal, pancreas, stomach, intestine, and skin were examined. Only the liver and kidneys showed degenerative changes. All such alterations resembled acute findings, with the exception of the nature of sudanophilic vacuolation of hepatocytes. Small lipid vacuoles, present in hepatocytes of repeatedly dosed rats, were distributed uniformly throughout the entire cytoplasm of each cell (Fig. 4). This finding was a marked contrast to the preponderance of large, distinct vacuoles noted in the acute studies. Minute necrotic foci were present in more severely affected areas.

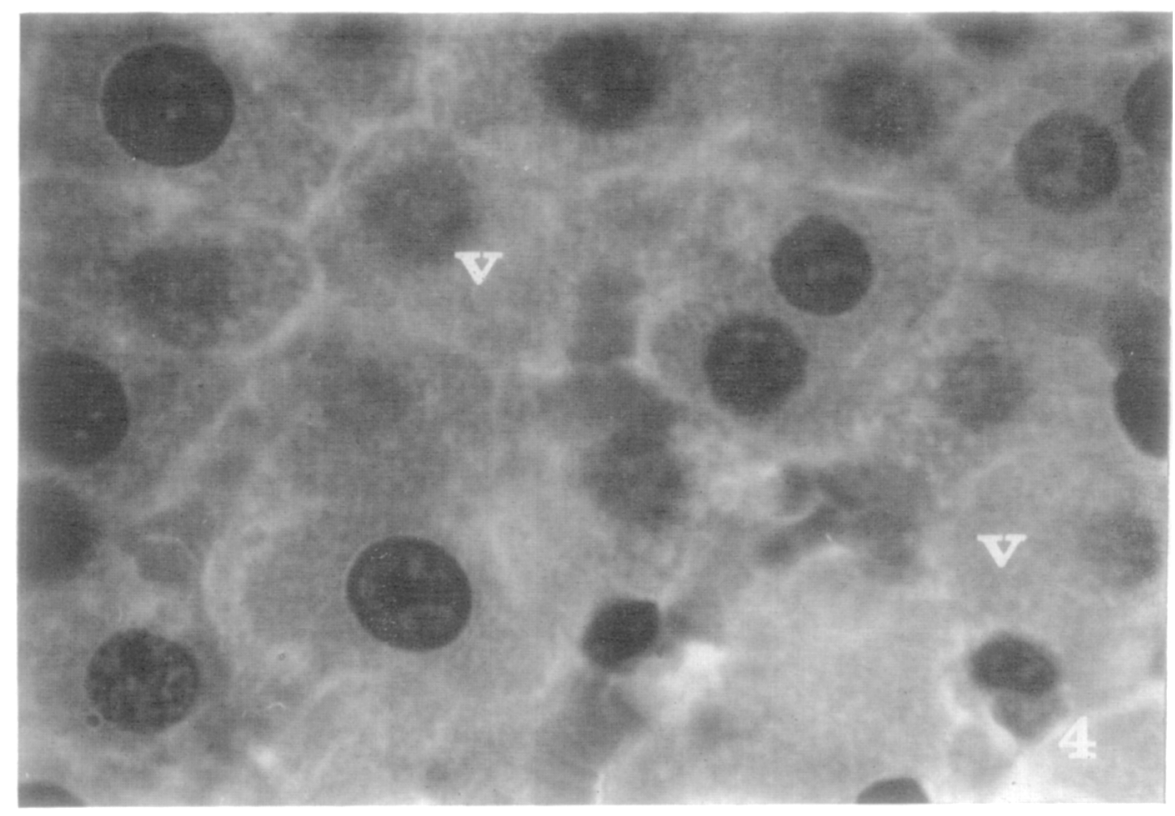

FIG. 4. Hepatocytes of a rat maintained on the subacute Aroclor 1242 dosage regimen. Observe the homogeneous distribution of minute lipid vacuoles $(v)$ throughout the cytoplasm of each cell. Hematoxylin and eosin. $\times 1200$.

The activities of selected enzymes were markedly higher in PCB-treated rats than in controls (Table 2). SGOT activities were two to three times higher than original values. Liver microsomal $\mathrm{N}$-demethylation of aminopyrine was also greater in test animals than in controls. Hydroxylation activity showed an extreme rise as evidenced by a greater than 10-fold elevation of hydroxylation of acetanilide.

\section{Microsomal Studies}

The effect on liver microsomal enzymes of a single dose of $100 \mathrm{mg} / \mathrm{kg}$ ip of Aroclor 1242 was studied in 4 groups of rats. Each group consisted of 6 PCB-treated and 3 control animals. Control animals received $100 \mathrm{mg} / \mathrm{kg}$ ip of peanut oil. Liver hydroxylation and $\mathrm{N}$-demethylation activities were measured 1,5 , and 10 days after dosing. Cytochrome $\mathrm{P}_{450}$ and $b_{5}$ concentrations were determined in the fourth group 5 days after treatment. 
BIOLOGICAL RESPONSES OF THE RAT TO PCBS

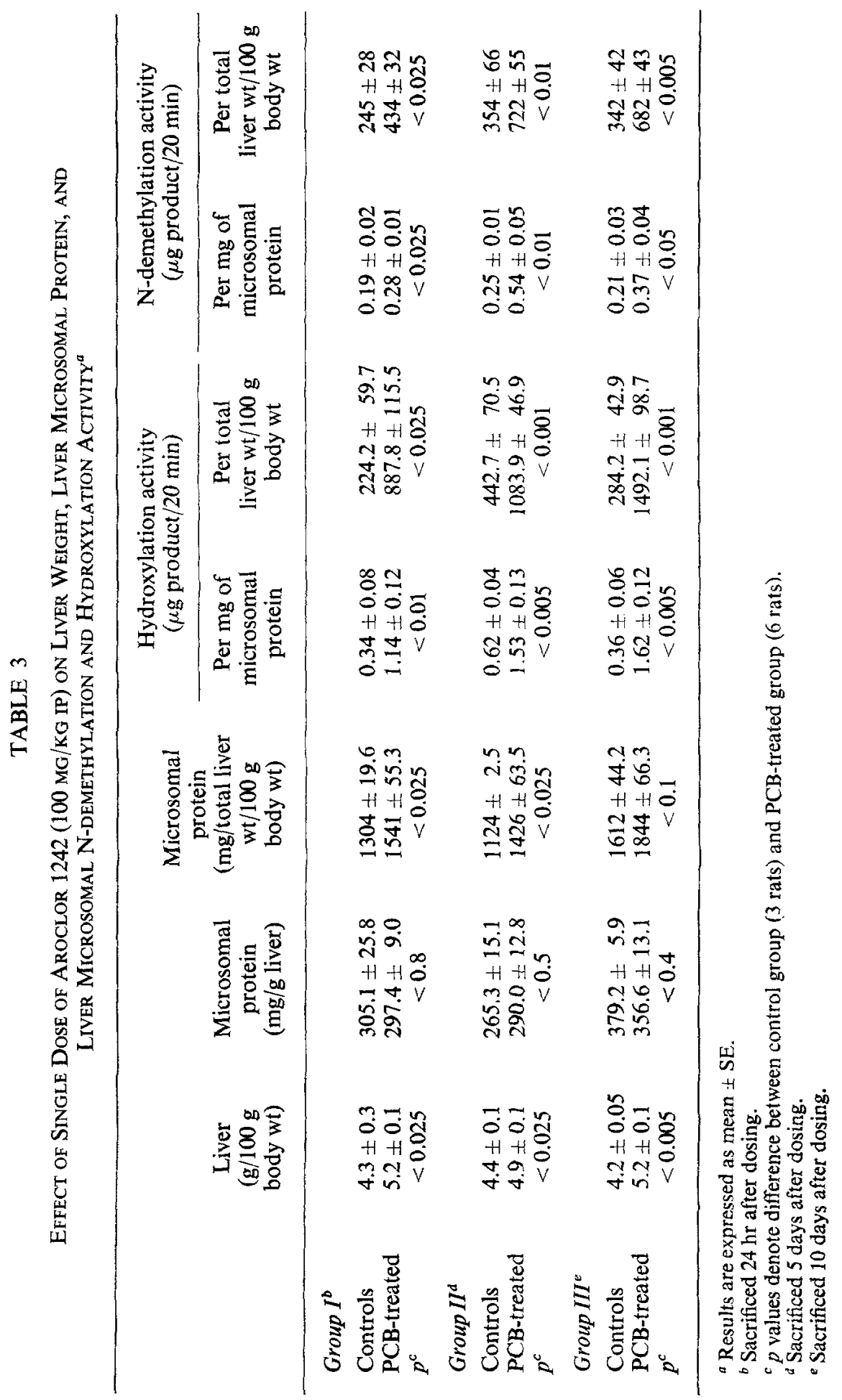




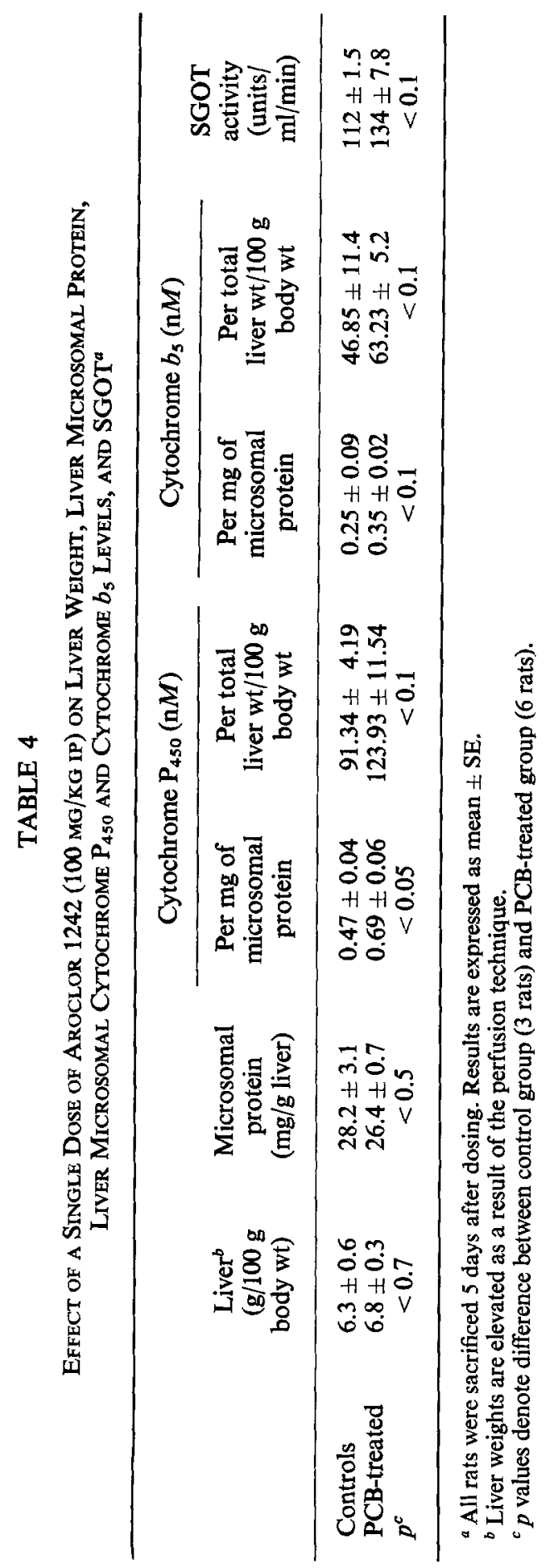


Liver weights of PCB-treated rats (Table 3 ) were increased over those of controls after $24 \mathrm{hr}$. N-demethylation activity was also elevated, while hydroxylation activity had markedly increased over control values. A similar pattern was evident in animals sacrificed both 5 and 10 days after dosing. Liver weights remained elevated in each group. $\mathrm{N}$-demethylation values also were greater than controls in each group, but were highest 5 days after injection of Aroclor 1242. Hydroxylation activity reached a maximum level in this study 10 days after the single injection.

The fourth group of rats was sacrificed 5 days after being dosed with $100 \mathrm{mg} / \mathrm{kg}$ po of Aroclor 1242 (Table 4). The mean cytochrome $\mathrm{P}_{450}$ concentration of PCB-treated rats, expressed per milligram of microsomal protein, was significantly different $(<0.05)$ from that of controls. Mean cytochrome $b_{5}$ concentrations of treated animals were also elevated in relation to controls; however, variability was such that $p$ values were slightly larger than 0.05 . The mean SGOT of treated rats was similarly higher than the control value, with $p<0.1$.

\section{DISCUSSION}

Signs of poisoning on acute, oral dosing with Aroclor 1242 suggest the existence of a dual mechanism of action of PCBs. Absence of response to pain stimuli, decrease in spontaneous activity and muscle tone, and abnormal locomotion with the hind quarters suggest neurologic and/or muscular involvement. High levels of PCB residues in chicken liver and brain were measured by Vos and Koeman (1970). On the basis of marked similarities in structure, properties, and storage within the CNS, one might anticipate DDT and PCB to elicit similar neurologic manifestations. However, DDT and its principal metabolites produce a contrasting syndrome in mammals, marked by increased excitability, muscular tremors and convulsions (Dale et al., 1963). The progressive ataxia and weakness noted in each subject in the present study is in direct contrast with such findings.

The second possible mechanism of acute toxicity entails dehydration. Although each subject receiving $\geqslant 4 \mathrm{~g} / \mathrm{kg}$ of Aroclor 1242 developed diarrhea, the precise means whereby the toxicant effected such an action is unclear. Although no control animal exhibited diarrhea, the laxative effect of Aroclor 1242 may have been mediated by a lubricating action on the bowel wall. Evidence of a marked irritant action on stomach or intestines was absent, since no signs of inflammation were evident on histopathologic examination. A mild irritant effect may have enhanced peristalsis, as deposits of mucus were noted on stools within $4 \mathrm{hr}$ of dosing. High levels of PCBs resulted in greatly decreased water intake and urinary output volumes, loss in body weight, and marked increase in packed cell volumes. Progressive dehydration, therefore, appeared to be a principal contributing factor in each fatality. Although damage to centers in the hypothalamus of rats has been demonstrated to produce aphagia and adipsia (Smith and McCann, 1962), no histopathologic lesions were evident in the hypothalamus of any subject in the present study.

Manifestations of acute hepatotoxicity in PCB-treated rats resembled those elicited by prolonged exposure to Aroclor 1242, differing principally in the nature and distribution of damaged cells. Acute high doses produced large, discrete sudanophilic vacuoles in hepatocytes, while prolonged dosing elicited a more uniform pattern, characterized by minute, multiple lipid vacuoles. These latter hepatic degenerative 
changes resembled those described in rabbits following prolonged exposure to Aroclor 1260 (Vos and Beems, 1971). Hepatocytes of control animals in the present study were characterized by a slight degree of sudanophilic vacuolation, indicative of the abnormally high amount of oil ingested. Since both control and test subjects received an equivalent volume of oil, the marked elevation in liver weight and extent of fatty vacuolation in the latter must be attributed to PCB-mediated effects other than exogenous oil deposition.

Widely scattered foci of vacuolated tubular epithelial cells were present in the kidneys of all rats dosed with Aroclor 1242. Such foci were more prominent in the prolonged dosing study than in the acute study. The histopathologic observation of sloughing tubular epithelium and of proteinaceous casts was supported by the presence of an elevated number of desquamated cells and leukocytes in the urine. Similar histopathologic findings were reported in rabbits following repeated topical application of Aroclor 1260 (Vos and Beems, 1971). Such damage, however, even when coupled with mild albuminuria, does not appear severe enough to account for the marked degree of oliguria observed in the acute study.

The absence of inflammation of abdominal and intestinal mucosa, following acute and prolonged exposure to undiluted Aroclor 1242, was surprising. Some degree of irritation, especially on prolonged dosing might be anticipated in view of reports of chloracne in humans (Meigs et al., 1954) and cutaneous lesions in rabbits (Vos and Beems, 1971). Differential leukocyte counts of blood smears from the acute study indicated a marked increase in circulating polymorphonuclear leukocytes. This response was probably a result of PCB-induced damage in the liver and kidneys. Elevation of SGOT activity following acute and prolonged dosing supports such evidence of organ damage.

In the subacute study, PCB-treated rats exhibited a decrease in packed cell volume from control values. Crenation of erythrocytes by acute, high doses of Aroclor 1242 may have resulted either from a direct action on cell membranes or from an osmotic effect. Previous reports have implicated PCBs in disruption of normal heme synthesis in chickens (Vos and Koeman, 1970), quail (Vos et al., 1971) and rabbits (Vos and Beems, 1971). Fluorescence in several tissues was observed in these studies. No fluorescence of tissues, however, was observed in the present investigation.

One of the most striking effects of Aroclor 1242 was its ability, even after a single low dose, to markedly increase liver weight. A number of factors may be implicated here. Most weight gain may be attributed to fatty deposition, as histopathology demonstrated multiple vacuoles of sudanophilic material in hepatocytes. A small proportion of this sudanophilic material is probably the test compound itself. Although relatively large proportions of PCB doses have been demonstrated in quail to be deposited in the liver (Vos et al., 1971), their contribution to total hepatic weight gains measured in the present study cannot be significant. Vos and co-workers also reported a rise in protein content of the mitochondrial fraction, upon administration of $100 \mathrm{mg} / \mathrm{kg}$ of Aroclor 1260. Increases of hepatic microsomal protein, following administration of Aroclor 1242 in the present investigation, were not evident when expressed per gram of liver. Apparently, concomitant deposition of lipid enhanced liver weights so as to mask increases in protein. When the same values were expressed in terms of milligrams of microsomal protein per total liver weight per $100 \mathrm{~g}$ body weight, elevations over 
control values became apparent. An electron microscopic study by Nishizumi (1970) demonstrated that prolonged dosing with a PCB mixture elicited a proliferation of membranes of smooth endoplasmic reticulum in liver cells of mice and monkeys. Such an alteration of cellular ultrastructure indicates a profound reorganization of structural and enzymatic proteins.

Aroclor 1242 proved to be both potent and selective in induction of rat liver microsomal enzymes. A single ip injection of $100 \mathrm{mg} / \mathrm{kg}$ of Aroclor 1242 enhanced N-demethylation of aminopyrine and hydroxylation of acetanilide for as long as 10 days. This ability to induce elevation of enzyme activity for prolonged periods may be attributed either to inability of the rat to readily metabolize PCBs, or to storage of significant amounts of PCBs in lipid depots, with subsequent release to the liver.

Hydroxylation activity was induced by Aroclor 1242 to a greater degree than was $\mathrm{N}$-demethylation. The prolonged dosing regimen enhanced hydroxylation by a factor of more than 10-fold. This selectivity might be anticipated on the basis of work done by Block and Cornish (1959), showing that biphenyl and 4-chlorobiphenyl are metabolized primarily by hydroxylation, with possible glucuronidation. Increased levels of cytochrome $\mathrm{P}_{450}$ and cytochrome $b_{5}$ were observed in the present study. It is generally accepted that increased levels of these cytochromes may be indicative of and intimately associated with enhanced microsomal oxidative capacity (Gillette, 1971).

The marked ability of Aroclor 1242 to induce hepatic microsomal enzyme activity and the long duration of increased activity seen after a single dose may be quite important. Induced microsomal enzyme activity alters the rate of metabolism and hence the toxicity of a variety of other environmental toxicants. Thus, PCBs may play a significant role in the biologic responses of mammals subjected to a variety of environmental chemical stresses.

\section{REFERENCES}

Biros, F. J., Walker, A. C. ANd Medbery, A. (1970). Polychlorinated biphenyls in human adipose tissue. Bull. Environ. Contam. Toxicol. 5, 317-323.

Block, W. D. ANd CoRnish, H. H. (1959). Metabolism of biphenyl and 4-chlorobiphenyl in the rabbit. J. Biol. Chem. 234, 3301-3303.

BouRne, W. AND MEAD, C. (1969). Seabird slaughter. B.T.O. News 36, 1-2.

BRODIE, B. B. AND AXELROD, J. (1948). The estimation of acetanilide and its metabolic products, aniline, $N$-acetyl-p-aminophenol and $p$-aminophenol (free and total conjugated) in biological fluids and tissues. J. Pharmacol. Exp. Ther. 94, 22-28.

Brodie, B. B. AND AXELrod, J. (1950). The fate of aminopyrine (Pyramidon) in man and methods for the estimation of aminopyrine and its metabolites in biological material. $J$. Pharmacol. Exp. Ther. 99, 171-184.

Dale, W. E., Gaines, T. B., Hayes, W. J., JR. and Pearce, G. W. (1963). Poisoning by DDT: Relation between clinical signs and concentration in rat brain. Science 142, 1474-1476.

Fujta, S., Tsujt, H., Kato, K., Saeki, S. and Tsukamoto, H. (1971). Effect of biphenyl chlorides on rat liver microsomes. Fukuoka Acta Med. 62, 30-34.

GrLlette, J. R. (1971). Factors affecting drug metabolism. Ann. N. Y. Acad. Sci. 179, 43-65. Gustafson, C. G. (1970). PCB's-prevalent and persistent. Environ. Sci. Technol. 4, 814-819. Koeman, J. H., ten Noever de Brauw, M. C. AND dE Vos, R. H. (1969). Chlorinated biphenyls in fish, mussels, birds from the river Rhine and Netherlands coastal area. Nature (London) 221, 1126-1128.

Kuratsune, M. (1969). An epidemiologic study on Yusho. Fukuoka Acta Med. 62, 513-532. LITCHFIELD, J. T., JR. AND WILCOXON, F. (1949). A simplified method of evaluating dose-effect experiments. J. Pharmacol. Exp. Ther. 96, 99-113. 
Meigs, J. W., Albom, J. J. And Kartin, B. L. (1954). Chloracne from an unusual exposure to Arochlor. J. Amer. Med. Ass. 154, 1417-1418.

NishIZUMI, M. (1970). Light and electron microscope study of chlorobiphenyl poisoning. Arch. Environ. Health 21, 620-632.

OMURA, T. AND SATo, R. (1964). The carbon monoxide-binding pigment of liver microsomes I. Evidence for its hemoprotein nature. J. Biol. Chem. 239, 2370-2378.

Peakall, D. B. And Lincer, J. L. (1970). Polychlorinated biphenyls. Another long-life widespread chemical in the environment. Bioscience 20, 958-964.

PiChirallo, J. (1971). PCB's: Leaks of toxic substances raises issue of effects, regulation. Science 173, 899-902.

RobInson, H. W. AND HoGden, C. G. (1940). The biuret reaction in the determination of serum proteins 1. A study of the conditions necessary for the production of a stable color which bears a quantitative relationship to the protein concentration. J. Biol. Chem. 135, 707-725.

Sigma Chemical Company (1963). Tech. Bull. No. 410.

SMrth, R. W. AND McCANN, S. M. (1962). Alterations in food and water intake after hypothalamic lesions in the rat. Amer. J. Physiol. 203, 366-370.

Vos, J. G. AND BeEMs, R. B. (1971). Dermal toxicity studies of technical polychlorinated biphenyls and fractions thereof in rabbits. Toxicol. Appl. Pharmacol. 19, 617-633.

Vos, J. G. AND KoEman, J. H. (1970). Comparative toxicologic study with polychlorinated biphenyls in chickens with special reference to porphyria, edema formation, liver necrosis, and tissue residues. Toxicol. Appl. Pharmacol. 17, 656-668.

Vos, J. G., Koeman, J. H., vaN DER MAas, H. L., TEN NoEver de Brauw, M. C. and de Vos, R. H. (1970). Identification and toxicological evaluation of chlorinated dibenzofuran and chlorinated naphthalene in two commercial polychlorinated biphenyls. Food Cosmet. Toxicol. 8, 625-633.

Vos, J. G., Strik, J. J. T. W. A., van Holsteÿn, W. M. and Pennings, J. H. (1971). Polychlorinated biphenyls as inducers of hepatic porphyria in Japanese quail, with special reference to $\delta$-aminolevulinic acid synthetase activity, fluorescence, and residues in the liver. Toxicol. Appl. Pharmacol. 20, 232-240. 